\title{
Perbedaan Peningkatan Kemampuan Pemecahan Masalah Matematis Siswa antara Think Pair Share dan Think Talk Write
}

\author{
Hilmi Ramdayani Fauziah Nur Hanifah ${ }^{1}$ dan Reni Nuraeni2 ${ }^{*}$ \\ Program Studi Pendidikan Matematika, Institut Pendidikan Indonesia \\ Jalan Pahlawan No. 32 Sukagalih, Tarogong Kidul, Garut, Jawa Barat, Indonesia \\ 1hilmiramdayani@gmail.com; ${ }^{2 *}$ reni.n2409@gmail.com
}

Artikel diterima: 25-11-2019, direvisi: 30-01-2020, diterbitkan: 31-01-2020

\begin{abstract}
Abstrak
Perlu adanya upaya guru untuk meningkatkan kemampuan pemecahan masalah matematis siswa, karena fakta di lapangan menunjukkan rendahnya kemampuan matematis siswa tersebut. Salah satunya penggunaan model pembelajaran kooperatif tipe Think Pair Share dan Think Talk Write. Penelitian ini dilakukan untuk menganalisis perbedaan peningkatan kemampuan pemecahan masalah matematis siswa antara yang mendapatkan model pembelajaran kooperatif tipe Think Pair Share dan Think Talk Write. Metode penelitiannya adalah kuasi eksperimen. Populasi penelitian yaitu seluruh siswa kelas VII MTs Negeri 1 Garut, dengan sampel sebanyak dua kelas yang terdiri dari 46 siswa. Instrumen penelitian yang digunakan berupa tes uraian. Analisis data diawali dengan uji gain ternormalisasi, uji normalitas data gain ternormalisasi, kemudian uji Mann Whitney. Berdasarkan hasil analisis secara statistik diperoleh kesimpulan bahwa terdapat perbedaan peningkatan kemampuan pemecahan masalah matematis siswa antara yang mendapatkan model pembelajaran Think Pair Share dan Think Talk Write.

Kata Kunci: Pemecahan masalah matematis, Think Pair Share, Think Talk Write.
\end{abstract}

\section{The Differences in Improving Students of Mathematical Problem Solving Ability Between Think Pair Share and Think Talk Write}

\begin{abstract}
Teachers need help to improve students 'mathematical problem-solving skills because the facts in the field show the students' low mathematical ability. One of them is the use of Think Pair Share and Think Talk Write cooperative learning models. This research was conducted to analyze the differences in the improvement of students' problem-solving skills between those who get the cooperative learning model Think Pair Share and Think Talk Write types. The research method is quasi-experiment. The study population was all grade VII students of MTs Negeri 1 Garut, with a sample of two classes consisting of 46 students. The research instrument used was a description test. Data analysis begins with the normalized gain test, the normalized normality gain data test, then the Mann Whitney test. Based on the analysis results obtained from the research results obtained from the comparison between students' mathematical problem solving between those who get the Think Pair Share learning model and Think Talk Write.

Keywords: Mathematical problem solving, Think Pair Share, Think Talk Write.
\end{abstract}




\section{Pendahuluan}

Salah satu mata pelajaran yang bisa memberikan fasilitas kepada siswa agar memiliki kemampuan berpikir serta kemampuan bekerja sama adalah pelajaran matematika. Kemampuan dalam mendapatkan dan mengolah informasi serta memanfaatkannya sebagai upaya untuk memecahkan masalah (Pratiwi, Rusdi, \& Putri, 2017) dalam berbagai bidang ilmu di kehidupan sehari-hari.

Permendikbud Nomor 58 Tahun 2014 menyebutkan bahwa "Matematika merupakan ilmu universal yang berguna bagi kehidupan manusia dan juga mendasari perkembangan teknologi modern, serta mempunyai peran penting dalam berbagai disiplin dan memajukan daya pikir manusia". "Kemampuan pemecahan masalah matematika adalah kemampuan matematis yang harus dimiliki oleh siswa" (NCTM, 2000).

Hasil penelitian Putra, dkk. (2018) mengungkapkan bahwa kemampuan pemecahan masalah matematis siswa tingkat SMP dikategorikan rendah, maka dari itu diperlukan upaya peningkatan. Siswa terlihat masih belum terbiasa mengerjakan soal-soal pemecahan masalah matematis sehingga kesulitan dalam memahami informasi yang terdapat di dalamnya. Oleh karena itu, siswa harus dilatih dalam mengerjakan soal yang diperlukan cara berpikir tingkat tinggi (Rahmatina, 2017), sehingga dapat memfasilitasi perkembangan kemampuan tersebut dengan baik.
Ini sesuai dengan hasil penelitian sebelumnya yaitu oleh Utami \& Wutsqa (2017) yang mengemukakan bahwa "Beberapa faktor yang diduga menyebabkan kemampuan pemecahan masalah siswa sangat rendah diantaranya, siswa belum terbiasa menyelesaikan soal rutin, siswa mudah menyerah dalam menyelesaikan soal, siswa kurang teliti dalam menyelesaikan soal, siswa kurang aktif untuk bertanya ketika menemukan hal-hal yang dianggap sulit, metode pembelajaran yang diterapkan guru kurang meningkatkan keaktifan siswa dalam belajar".

Peran guru untuk membiasakan siswa menyelesaikan soal pemecahan masalah matematis sangat penting (Wardani, 2012). Ini akan membuat siswa memiliki pandangan bahwa matematika akan lebih mudah dimengerti dan bermakna (Afriansyah \& Dahlan, 2017), karena siswa akan terbantu dalam mempelajari bagaimana menyelesaikan suatu persoalan dan akan melihat bahwa matematika merupakan ilmu yang logis dan banyak kegunaanya dalam kehidupan manusia.

Sejalan dengan pentingnya kemampuan matematis tersebut, diperlukan adanya inovasi maupun upaya yang dilakukan dalam pembelajaran, yaitu dengan mencari suatu pembelajaran yang cocok dengan tujuan yang telah ditentukan. Salah satunya dengan penggunaan pembelajaran kooperatif. Pembelajaran kooperatif merupakan suatu pembelajaran yang memfasilitasi siswa untuk bekerja 
dalam kelompok yang kemampuan akademisnya heterogen, sampai siswa mampu mempresentasikan hasil kerja bersama kelompoknya (Supriatna \& Afriansyah, 2018). Model pembelajaran kooperatif yang sesuai dan memiliki karakter untuk menyelesaikan berbagai masalah tersebut adalah model pembelajaran kooperatif tipe Think Pair Share dan Think Talk Write.

Menurut Arends, Prajitno \& Mulyantini (Hidayati, 2017), "Model pembelajaran Think Pair Share merupakan cara efektif untuk membuat variasi suasana pola diskusi di kelas". Model pembelajaran lain yang diyakini juga dapat memfasilitasi peningkatan kemampuan pemecahan masalah matematis siswa adalah Think Talk Write. Ini didukung oleh hasil penelitian yang dilakukan oleh Fajar \& Sudia (2016) bahwa "Terdapat peningkatan kemampuan pemecahan masalah matematis setelah mengikuti pembelajaran dengan model pembelajaran Think Talk Write".

Dalam penelitian ini, peneliti mengkaji: 1) perbedaan peningkatan kemampuan pemecahan masalah matematis antara

Tabel 1.

Rubrik Penskoran

\begin{tabular}{|c|c|c|c|c|}
\hline \multirow[t]{2}{*}{ Skor } & \multicolumn{4}{|c|}{ Indikator Kemampuan Pemecahan Masalah } \\
\hline & $\begin{array}{l}\text { Mengidentifikasi } \\
\text { unsur-unsur yang } \\
\text { diketahui, yang } \\
\text { ditanyakan, dan } \\
\text { kecukupan unsur } \\
\text { yang diperlukan }\end{array}$ & $\begin{array}{c}\text { Merumuskan masalah } \\
\text { matematik atau } \\
\text { menyusun model } \\
\text { matematik }\end{array}$ & $\begin{array}{l}\text { Menerapkan strategi } \\
\text { untuk menyelesaikan } \\
\text { berbagai masalah } \\
\text { (sejenis dan masalah } \\
\text { baru) dalam atau di } \\
\text { luar matematika }\end{array}$ & $\begin{array}{c}\text { Menjelaskan atau } \\
\text { menginterpretasikan } \\
\text { hasil sesuai } \\
\text { permasalahan asal }\end{array}$ \\
\hline 0 & \multicolumn{4}{|c|}{ Tidak ada jawaban atau jawaban tidak ada hubungannya dengan soal. } \\
\hline 1 & $\begin{array}{c}\text { Dapat } \\
\text { mengidentifikasikan } \\
\text { tetapi tidak lengkap } \\
\text { dan tidak benar }\end{array}$ & $\begin{array}{c}\text { Dapat merumuskan } \\
\text { masalah atau menyusun } \\
\text { model tetapi tidak } \\
\text { lengkap dan tidak benar }\end{array}$ & $\begin{array}{c}\text { Dapat menerapkan } \\
\text { strategi tetapi tidak } \\
\text { lengkap dan tidak } \\
\text { benar }\end{array}$ & $\begin{array}{c}\text { Dapat menjelaskan atau } \\
\text { menginterpretasikan } \\
\text { hasil tetapi tidak } \\
\text { lengkap dan tidak benar }\end{array}$ \\
\hline 2 & $\begin{array}{c}\text { Dapat } \\
\text { mengidentifikasikan } \\
\text { dengan lengkap } \\
\text { tetapi tidak benar }\end{array}$ & $\begin{array}{c}\text { Dapat merumuskan } \\
\text { masalah dengan lengkap } \\
\text { tetapi tidak benar }\end{array}$ & $\begin{array}{c}\text { Dapat menerapkan } \\
\text { strategi dengan } \\
\text { lengkap tetapi tidak } \\
\text { benar }\end{array}$ & $\begin{array}{c}\text { Dapat menjelaskan atau } \\
\text { menginterpretasikan } \\
\text { hasil dengan lengkap } \\
\text { tetapi tidak benar }\end{array}$ \\
\hline 3 & $\begin{array}{c}\text { Dapat } \\
\text { mengidentifikasikan } \\
\text { dengan benar tetapi } \\
\text { tidak lengkap }\end{array}$ & $\begin{array}{c}\text { Dapat merumuskan } \\
\text { masalah atau menyusun } \\
\text { model dengan benar } \\
\text { tetapi tidak lengkap }\end{array}$ & $\begin{array}{l}\text { Dapat menerapkan } \\
\text { strategi dengan benar } \\
\text { tetapi tidak lengkap }\end{array}$ & $\begin{array}{c}\text { Dapat menjelaskan atau } \\
\text { menginterpretasikan } \\
\text { hasil dengan benar } \\
\text { tetapi tidak lengkap }\end{array}$ \\
\hline 4 & $\begin{array}{c}\text { Dapat } \\
\text { mengidentifikasikan } \\
\text { dengan lengkap dan } \\
\text { benar }\end{array}$ & $\begin{array}{c}\text { Dapat merumuskan } \\
\text { masalah atau menyusun } \\
\text { model dengan lengkap } \\
\text { dan benar }\end{array}$ & $\begin{array}{l}\text { Dapat menerapkan } \\
\text { strategi dengan } \\
\text { lengkap dan benar }\end{array}$ & $\begin{array}{c}\text { Dapat menjelaskan atau } \\
\text { menginterpretasikan } \\
\text { hasil dengan lengkap } \\
\text { dan benar }\end{array}$ \\
\hline
\end{tabular}

\section{Mosharafa: Jurnal Pendidikan Matematika}


siswa yang mendapatkan model macam jawaban. Tahap dua, pair pembelajaran Think Pair Share dengan (berpasangan). Pada tahap ini siswa Think Talk Write. 2) peningkatan kemampuan pemecahan masalah matematis siswa yang mendapatkan model pembelajaran Think Pair Share. 3) peningkatan kemampuan pemecahan masalah matematis siswa yang mendapatkan model pembelajaran Think Talk Write.

Indikator pemecahan masalah matematis yang digunakan oleh peneliti, adalah indikator menurut NCTM (1989) yaitu: "Mengidentifikasi unsur-unsur yang diketahui, yang ditanyakan, dan kecukupan unsur yang diperlukan; Merumuskan masalah matematik atau menyusun model matematik; Menerapkan strategi untuk menyelesaikan berbagai masalah (sejenis dan masalah baru) dalam atau di luar matematika; dan Menjelaskan atau menginterpretasikan hasil sesuai permasalahan asal." Sementara itu, rubrik penskorannya disajikan pada tabel 1 .

Model pembelajaran Think Pair Share memiliki tahapan pembelajaran sebagai berikut, (Shoimin, 2014): "Tahap satu, think (berpikir). Pada tahap ini guru memberikan pertanyaan yang berkaitan dengan materi yang akan dipelajari. Proses Think Pair Share dimulai pada saat ini, yaitu dimana guru mengemukakan pertanyaan berupa suatu permasalahan yang dapat merangsang kemampuan berpikir ke seluruh kelas. Pertanyaan ini hendaknya pertanyaan terbuka yang memungkinkan dijawab dengan berbagai berpikir secara individu. Guru meminta kepada siswa untuk berpasangan dan mulai memikirkan pertanyaan atau masalah yang diberikan dalam waktu tertentu. Lamanya waktu ditetapkan berdasarkan pemahaman guru terhadap karakter siswanya, sifat pertanyaannya, dan jadwal pembelajaran. Siswa disarankan untuk menulis jawaban atau pemecahan masalah dari hasil pemikirannya. Tahap tiga, share (berbagi). Pada tahap ini siswa secara individu mewakili kelompok atau berpasangan, melaporkan hasil diskusinya di depan kelas. Pada tahap akhir ini seluruh siswa akan mendapatkan keuntungan yaitu dalam bentuk mendengarkan berbagai ungkapan mengenai konsep yang sama tetapi dinyatakan dengan cara yang berbeda oleh individu yang berbeda."

Sedangkan tahapan pembelajaran Think Talk Write sebagai berikut, (Lestari \& Yudhanegara, 2015): "Teams (Berkelompok), pada tahap ini dilakukan pembentukan kelompok yang terdiri atas 3-5 orang anggota yang heterogen agar dalam setiap kelompok terdapat kemampuan siswa yang berbeda-beda sehingga terdapat siswa yang membantu anggota lain dalam menyelesaikan masalah. Think (Berpikir), tahap berpikir ini siswa diminta untuk membaca teks berupa soal dan secara individu memikirkan kemungkinan jawaban (strategi penyelesaian), membuat catatan kecil 
berupa ide-ide yang terdapat pada bacaan, atau hal-hal yang tidak dipahaminya sesuai dengan bahasanya sendiri. Talk (Berbicara), pada tahap ini siswa merefleksikan, menyusun serta menguji ide-ide dalam kegiatan diskusi kelompok. Selanjutnya para siswa berkomunikasi dengan menggunakan kata-kata dan bahasa yang mereka pahami. Siswa menyampaikan ide yang diperoleh pada tahap think kepada teman-teman diskusi sekelompoknya yaitu dengan mem-bahas hal-hal yang diketahui dan tidak diketahuinya. Write (Menulis), pada tahap ini, siswa secara individu merumuskan pengetahuan berupa jawaban atas soal yang memuat landasan dan keterkaitan konsep serta strategi dan solusinya dalam bentuk tulisan (write) menggunakan bahasanya sendiri. Pada tulisan itu, siswa menghubungkan ide-ide yang diperolehnya melalui diskusi".

\section{Metode}

Metode penelitian yang digunakan adalah kuasi eksperimen, artinya pengambilan subjek yang akan diteliti tidak dilakukan secara acak. Akan tetapi, sesuai dengan penelitian Pitriani \& Afriansyah (2017), sampel penelitian menggunakan kelompok yang sudah ada atau siswa yang terdaftar di kelas masingmasing, karena tidak memungkinkan membuat kelompok baru secara acak.

Penelitian ini dilakukan pada bulan April 2019 sampai Mei 2019 sebanyak 5 kali pertemuan dengan materi segitiga. Dalam penelitian ini populasinya yaitu siswa MTs Negeri 1 Garut kelas VII Tahun Pelajaran 2018-2019 Semester Genap. Sampel yang digunakan sebanyak dua kelas yaitu kelas VII-9 sebagai kelas eksperimen I (yang mendapatkan model pembelajaran Think Pair Share) dan kelas VII-12 sebagai kelas eksperimen II (yang mendapatkan model pembelajaran Think Talk Write). Peneliti melakukan ini dikarenakan siswa mendapatkan materi berdasarkan kurikulum yang sama, siswa juga berada pada tingkatan kelas yang sama, dan pengelompokkan kelas tidak ada kelas unggulan. Dengan demikian, karakteristik pembelajaran dan kemampuan awal siswa sama. Instrumen yang digunakan dalam penelitian ini berupa tes uraian yang terdiri dari 4 butir soal pemecahan masalah.

Dalam penelitian ini, desain penelitian yang digunakan adalah The Nonequivalent Pretest Posttest Control Group Design yang terdiri dari dua kelompok dan ditentukan dengan tujuan (purposive sampling). Kedua kelompok tersebut mendapatkan perlakuan yang berbeda dan digambarkan sebagai berikut:

\begin{tabular}{ccc}
0 & $x 1$ & 0 \\
\hline 0 & $x 2$ & 0
\end{tabular}

(Lestari dan Yudhanegara, 2015)

Keterangan:

O : Instrumen tes awal (pretest) dan tes akhir (posttest).

X1 : Perlakuan dengan model pembelajaran Think Pair Share. 
X2 : Perlakuan dengan model pembelajaran Think Talk Write.

--- : Subjek (siswa) tidak dikelompokkan secara acak.

Analisis data yang digunakan pada penelitian ini adalah statistika Inferensial, karena metode pada penelitian ini berhubungan dengan analisis data pada sampel dan hasilnya dipakai untuk menarik kesimpulan pada populasi. Penelitian ini juga termasuk statistika non parametrik dikarenakan data yang diperoleh salah satunya tidak berdistribusi normal. Analisis data dilakukan untuk mengetahui hasil dari penelitian setelah diberikan perlakuan model pembelajaran. Data yang diperoleh adalah hasil pretest, posttest, dan gain ternormalisasi. Dalam hal ini, analisis data diawali dengan uji gain ternormalisasi, uji normalitas data gain ternormalisasi dan uji Mann Whitney. Adapun interpretasi data gain ternormalisasi disajikan pada tabel 2 .

\section{Hasil dan Pembahasan}

Penelitian dilakukan sebanyak 5 kali pertemuan. Dua kelas eksperimen yang masing-masing memperoleh perlakuan

Tabel 2

Interpretasi Gain Ternormalisasi yang Dimodifikasi

\begin{tabular}{rc|}
\hline $\begin{array}{c}\text { Nilai Gain } \\
\text { Ternormalisasi }\end{array}$ & Interpretasi \\
\hline$-1,00 \leq \mathrm{g}<0,00$ & Terjadi penurunan \\
\hline $\mathrm{g}=0,00$ & Tidak terjadi peningkatan \\
\hline $0,00<\mathrm{g}<0,30$ & Rendah \\
\hline $0,30 \leq \mathrm{g}<0,70$ & Sedang \\
\hline $0,70 \leq \mathrm{g} \leq 1,00$ & Tinggi \\
& (Sundavana. 2016) \\
\hline
\end{tabular}

yang berbeda, masing-masing mendapatkan model pembelajaran Think Pair Share dan Think Talk Write. Berikut disajikan tabel 3 data hasil penelitian dari kedua kelas eksperimen.

Dari Tabel 3 diperoleh bahwa nilai ratarata gain pada kelas Think Talk Write lebih besar dibandingkan dengan kelas Think Pair Share. Hal tersebut menunjukkan bahwa peningkatan kemampuan pemecahan masalah matematis siswa setelah diberikan perlakuan dengan model pembelajaran yang berbeda pada masingmasing kelas ternyata memiliki perbedaan peningkatan. Peningkatan kemampuan pemecahan masalah kelas Think Talk Write lebih baik.

Adapun rincian kualitas peningkatan

Tabel 3

Data Hasil Penelitian

\begin{tabular}{|c|c|c|c|c|c|c|}
\hline \multicolumn{2}{|c|}{ Kelompok } & $n$ & $X_{\text {maks }}$ & $X_{\min }$ & $\bar{x}$ & $S$ \\
\hline \multirow[t]{3}{*}{ TPS } & Pretest & \multirow[t]{3}{*}{20} & 10 & 1 & 3,45 & 1,93 \\
\hline & Posttest & & 13 & 4 & 7,00 & 2,85 \\
\hline & $N$-gain & & 0,58 & 0,08 & 0,29 & 0,16 \\
\hline \multirow[t]{3}{*}{ TTW } & Pretest & \multirow[t]{3}{*}{26} & 12 & 1 & 4,42 & 3,29 \\
\hline & Posttest & & 15 & 3 & 9,00 & 3,64 \\
\hline & $N$-gain & & 0,86 & 0,08 & 0,42 & 0,21 \\
\hline
\end{tabular}

Tabel 4

Data Presentase Interpretasi Peningkatan Kemampuan Pemecahan Masalah Matematis Kelas Model Pembelajaran Think Pair Share dan Think Talk Write

\begin{tabular}{|cccccc|}
\hline No. & $\begin{array}{c}\text { Interpretasi } \\
\text { Gain } \\
\text { Ternormalisasi }\end{array}$ & \begin{tabular}{c} 
Think \\
Pair \\
\cline { 3 - 6 }
\end{tabular} & \multicolumn{2}{c}{$\begin{array}{c}\text { Share } \\
\text { Write }\end{array}$} \\
\cline { 3 - 6 } & $\mathrm{f}_{\mathrm{i}}$ & $\mathbf{( \% )}$ & $\mathrm{f}_{\mathrm{i}}$ & $(\%)$ \\
\hline 1 & Tinggi & 0 & 0 & 2 & 7,69 \\
\hline 2 & Sedang & 9 & 45 & 16 & 61,54 \\
\hline 3 & Rendah & 11 & 55 & 8 & 30,77 \\
\hline 4 & Tetap & 0 & 0 & 0 & 0 \\
\hline & Jumlah & 20 & 100 & 26 & 100 \\
\hline
\end{tabular}


kedua kelompok eksperimen disajikan pada tabel 4.

Selain itu, jika dilihat dari pencapaian indikator kemampuan pemecahan masalah matematis siswa, diperoleh data yang disajikan pada tabel 5 .

Dari Tabel 5 dapat dilihat bahwa tidak ada satupun indikator yang mencapai ketuntasan pada kelompok kelas dengan model pembelajaran Think Pair Share, sedangkan pada kelompok kelas dengan model pembelajaran Think Talk Write terdapat dua indikator yang mencapai ketuntasan.

Sebelum masing-masing kelas eksperimen diberikan perlakuan yang berbeda, kedua kelas diberikan pretest terlebih dahulu dengan tujuan untuk mengetahui kemampuan pemecahan masalah matematis awal yang dimiliki kedua kelas relatif sama atau tidak. Serta untuk mengetahui sejauh mana kemampuan awal yang dimiliki.

Setelah melakukan pembelajaran dengan materi segitiga yang masingmasing kelas menggunakan model pembelajaran yang berbeda sebanyak 3 kali pertemuan, peneliti melakukan posttest untuk mengetahui apakah siswa

Tabel 5

Pencapaian Masing-masing Indikator Kemampuan Pemecahan Masalah Matematis

\begin{tabular}{ccccc}
\hline Kelompok & \multicolumn{4}{c}{$\begin{array}{c}\text { Nomor Indikator Pemecahan } \\
\text { Masalah }\end{array}$} \\
\cline { 2 - 5 } & $\mathbf{1}$ & $\mathbf{2}$ & $\mathbf{3}$ & $\mathbf{4}$ \\
\hline Kelas TPS & Tidak & Tidak & Tidak & Tidak \\
& Tuntas & Tuntas & Tuntas & Tuntas \\
\hline Kelas TTW & Tuntas & Tidak & Tuntas & Tidak \\
& & Tuntas & & Tuntas
\end{tabular}

memahami materi yang telah diberikan serta mengatahui sejauh mana kemampuan akhir yang dimiliki siswa.

Langkah selanjutnya yaitu uji gain ternormalisasi, hal ini dilakukan untuk mengetahui apakah terdapat perbedaan peningkatan kemampuan pemecahan masalah matematis antara siswa yang mendapatkan model pembelajaran Think Pair Share dan model pembelajaran Think Talk Write. Sehingga didapat rata-rata data gain ternormalisasi pada masing-masing kelas yaitu 0,29 dan 0,42.

\section{A. Uji Normalitas Data Gain}

Berdasarkan Tabel 6, dengan menggunakan taraf signifikan ( $\alpha$ ) 5\% perhitungan uji normalitas data gain ternormalisasi kelas eksperimen I, diketahui bahwa nilai $L_{\text {maks }}=0,1962 \geq$ $L_{\text {tabel }}=0,1950$ maka data hasil gain ternormalisasi kelas Think Pair Share tidak berdistribusi normal. Sedangkan untuk kelas eksperimen II, diketahui bahwa nilai $L_{\text {maks }}=0,1106>L_{\text {tabel }}=0,1730$ maka data hasil gain ternormalisasi kelas Think Talk Write berdistribusi normal.

\section{B. Uji Mann Whitney}

Hasil uji normalitas menyatakan bahwa sebaran data pada salah satu kelas yaitu kelas Think Pair Share tidak berdistribusi normal, sehingga tahap pengujian selanjutnya adalah Uji Mann Whitney.

Tabel 6

Hasil Uji Normalitas Data Gain Ternormalisasi

\begin{tabular}{ccc}
\hline Kelompok & Lmaks & Ltabel \\
\hline Kelas TPS & 0,1962 & 0,1950 \\
\hline Kelas TTW & 0,1106 & 0,1730 \\
\hline
\end{tabular}


Hasil analisis data gain ternormalisasi dengan uji Mann Whitney menunjukkan nilai $z_{\text {hitung }}$ tidak berada pada daerah penerimaan $H_{0}$ yaitu $-1,96<2,17<$ 1,96 maka dapat disimpulkan bahwa terdapat perbedaan peningkatan kemampuan pemecahan masalah matematis antara siswa yang mendapatkan model pembelajaran Think Pair Share dan siswa yang mendapatkan model pembelajaran Think Talk Write.

\section{Peningkatan \\ Kemampuan \\ Pemecahan Masalah Matematis}

Berdasarkan Tabel 7 diketahui bahwa rata-rata skor gain ternormalisasi kelas eksperimen I yaitu 0,29 dengan interpretasi rendah, dan kelas eksperimen II yaitu 0,42 dengan interpretasi sedang. Sehingga dapat disimpulkan bahwa peningkatan kemampuan pemecahan masalah matematis siswa yang mendapatkan model pembelajaran Think Pair Share tergolong rendah, dan siswa yang mendapatkan model pembelajaran Think Talk Write tergolong sedang.

Hasil analisis data menunjukkan bahwa terdapat perbedaan peningkatan kemampuan pemecahan masalah matematis dari kedua kelas eksperimen, dimana kelas yang mendapatkan model

Tabel 7

Peningkatan Kelas Eksperimen I dan II

\begin{tabular}{ccc}
\hline $\begin{array}{c}\text { Model } \\
\text { Pembelajaran }\end{array}$ & TPS & TTW \\
\hline $\begin{array}{c}\text { Rata-rata } \\
\text { Skor Gain } \\
\text { Ternormalisasi }\end{array}$ & 0,29 & 0,42 \\
\hline Interpretasi & Rendah & Sedang \\
\hline
\end{tabular}

pembelajaran Think Talk Write cenderung memiliki kadar peningkatan yang lebih tinggi dibandingkan dengan kelas yang mendapatkan model pembelajaran Think Pair Share. Hal tersebut diketahui berdasarkan interpretasi gain ternormalisasi dari kedua kelas ekpsperimen yang menunjukkan perbedaan peningkatan keduanya.

Faktor-faktor yang mempengaruhi hasil penelitian ini antara lain:

1. Aktivitas Siswa dalam Proses Pembelajaran

Pembelajaran matematika di kelas pada pertemuan sebelum penelitian dimulai menunjukkan bahwa soal yang diberikan kepada siswa hanya terbatas pada soal yang terdapat pada buku pegangan siswa saja. Hal itu menyebabkan pada proses penelitian siswa belum terbiasa menyelesaikan soal rutin maupun non rutin karena kemampuan pemecahan masalah matematisnya masih kurang.

Dilihat dari keseluruhan, setiap tahap/fase pada kedua model pembelajaran hampir sama. Kegiatan pembelajaran berpusat pada siswa, dan peneliti hanya bertindak sebagai fasilitator dengan menyediakan Lembar Kegiatan Siswa pada setiap pertemuan. Siswa dari kedua kelas eksperimen dibagi menjadi beberapa kelompok yang beranggotakan 2 orang pada kelas eksperimen I dan beberapa kelompok yang beranggotakan 3-5 orang pada kelas eksperimen II. Pada setiap pertemuan, disajikan sebuah permasalahan yang berkaitan dengan 
materi yang akan dipelajari, dan siswa diarahkan untuk mempelajari serta memikirkan kemungkinan jawaban permasalahan tersebut secara individu. Kemudian siswa diminta untuk mendiskusikan kemungkinan jawaban permasalahan tersebut bersama kelompoknya. Setelah itu, siswa mempresentasikan hasil diskusi yang telah disepakati dengan teman sekelompoknya di depan kelas dan siswa lain bertanya atau menanggapi hasil yang dipresentasikan oleh kelompok tersebut.

Selain faktor langkah-langkah dalam model pembelajaran Think Pair Share dan Think Talk Write, faktor lain yang menyebabkan adanya perbedaan peningkatan kemampuan pemecahan masalah matematis siswa yang mendapatkan model pembelajaran Think Pair Share dan Think Talk Write adalah karena adanya kelebihan dan kekurangan dari kedua model tersebut.

2. Model Pembelajaran yang Digunakan

Kedua model pembelajaran yang digunakan tersebut sama-sama mempunyai tahapan mempelajari terlebih dahulu secara individu, kemudian mendiskusikan permasalahan tersebut secara berkelompok dan mempresentasikan hasil diskusi kelompoknya di depan kelas.

Dalam proses pembelajaran, masingmasing siswa memiliki karakteristik atau gaya belajar yang berbeda-beda untuk berkonsentrasi pada proses, menguasai informasi yang baru serta sulit melalui persepsi yang berbeda. Dengan kata lain setiap siswa diasumsikan memiliki pilihan gaya belajar tersendiri untuk membantu belajar mereka dalam suatu situasi yang telah dikondisikan. "Sehingga faktor perbedaan gaya belajar dapat menyebabkan terjadinya perbedaan dalam pemahaman terhadap suatu informasi dan dapat menyebabkan terjadinya perbedaan dalam menyelesaikan masalah pada setiap individu" (Ilmiyah \& Marsiyah, 2013).

Perbedaan peningkatan kemampuan pemecahan masalah matematis disebabkan karena siswa merasa belum terbiasa mengerjakan soal-soal yang diberikan oleh peneliti, model pembelajaran yang dianggap masih baru sehingga siswa belum terbiasa dalam melaksanakannya, hal ini sejalan dengan penelitian yang dilakukan oleh Sopian dan Afriansyah (2017). Selain itu, siswa yang memperoleh model pembelajaran Think Pair Share selalu mendapat jadwal pelajaran pada waktu siang hari sehingga kemampuan maupun respon siswa terhadap kegiatan pembelajaran terkadang sedikit menurun dan menyebabkan rendahnya daya serap siswa terhadap materi segitiga yang diberikan serta kurangnya motivasi dan minat belajar siswa. Sedangkan dengan tingginya motivasi, siswa menjadi lebih aktif dan lebih berani bahkan percaya diri dalam bertanya kepada guru jika menghadapi kesulitan dalam proses pembelajaran. Motivasi merupakan suatu dorongan, kekuatan, atau alasan yang menjadi dasar 
semangat seorang individu dalam melakukan sesuatu hingga ia dapat mencapai tujuan tertentu. Oleh sebab itu, "Keberagaman tingkat motivasi belajar siswa menyebabkan pembelajaran di kelas belum terlaksana maksimal, sehingga mempengaruhi proses pemecahan masalah matematikanya" (Ulya, 2016).

3. Analisis Jawaban Siswa

Terlihat dari cara penyelesaian siswa pada kedua kelas, siswa masih belum memahami benar mengenai maksud dari soal mencari luas suatu daerah pada materi segitiga dan langkah-langkah penyelesaian soal yang tepat. Hal itu juga yang menunjukkan bahwa indikator kemampuan pemecahan masalah matematis dalam menjelaskan atau menginterpretasikan hasil sesuai permasalahan asal di kedua kelas setelah diberikan perlakuan model pembelajaran Think Pair Share maupun Think Talk Write tidak menunjukkan ketuntasan jika dibandingkan dengan nilai KKM.

Selain dari indikator yang diteliti, daya serap siswa setelah diberikan model pembelajaran Think Pair Share maupun Think Talk Write terhadap ketercapaian KKM yang telah ditetapkan masih rendah, disajikan pada tabel 8.

Tabel 8

Rekapitulasi Pencapaian KKM

\begin{tabular}{ccccc|}
\hline \multirow{2}{*}{ Ketuntasan } & \multicolumn{2}{c}{ TPS } & \multicolumn{3}{c}{ TTW } \\
\cline { 2 - 5 } & Frekuensi & $\%$ & Frekuensi & $\%$ \\
\hline Tuntas & 2 & 10 & 11 & 42,31 \\
\hline Tidak \\
Tuntas
\end{tabular}

Dari tabel tersebut dengan $\mathrm{KKM}=65$, diperoleh bahwa untuk kelas yang mendapatkan model pembelajaran Think Pair Share lebih banyak siswa yang belum tuntas mencapai KKM dibandingkan kelas yang mendapatkan model pembelajaran Think Talk Write.

Dokumentasi saat pelaksanaan kegiatan pembelajaran berlangsung disajikan pada gambar berikut.

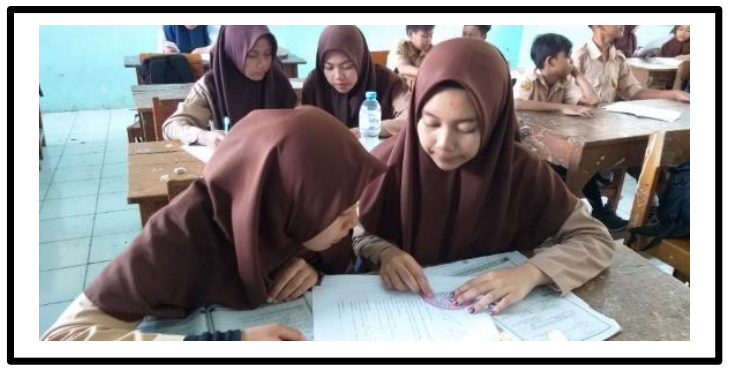

Gambar 1. Kegiatan Pembelajaran Kelas Think Pair Share.

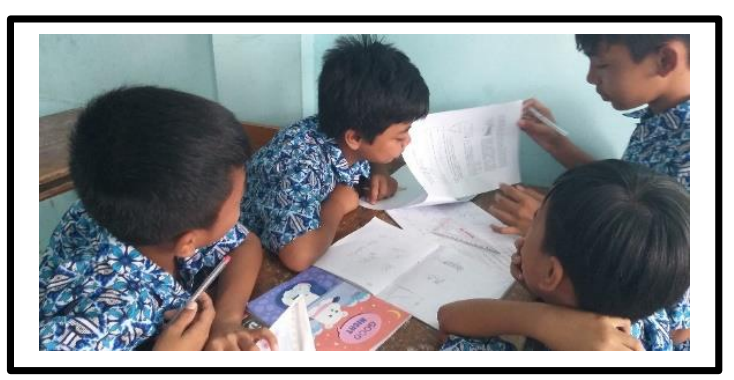

Gambar 2. Kegiatan Pembelajaran Kelas Think Talk Write.

\section{Penutup}

Berdasarkan hasil analisis data serta pembahasan secara keseluruhan, diperoleh kesimpulan: 1) Terdapat perbedaan peningkatan kemampuan pemecahan masalah matematis antara siswa yang mendapatkan model pembelajaran Think Pair Share dan Think 
Talk Write. 2) Peningkatan kemampuan pemecahan masalah matematis siswa yang mendapatkan model pembelajaran Think Pair Share berdasarkan hasil analisis data gain ternormalisasi memperoleh interpretasi rendah. 3) Peningkatan kemampuan pemecahan masalah matematis siswa yang mendapatkan model pembelajaran Think Talk Write berdasarkan hasil analisis data gain ternormalisasi memperoleh interpretasi sedang.

\section{Daftar Pustaka}

Afriansyah, E. A., \& Dahlan, J. A. (2017). Design Research in Fraction for Prospective Teachers. The 5th SEA-DR (South East Asia Development Research) International Conference 2017 (SEADRIC 2017). Advances in Social Science, Education. 91-97.

Fajar, L. O. M. S \& Sudia, M. (2016). Penerapan Model TTW (Think Talk Write) sebagai Upaya Meningkatkan Kemampuan Pemecahan Masalah Matematika Siswa Kelas VII-5 SMPN 2 Raha. Jurnal Penelitian Pendidikan Matematika, 4(1), 85-98.

Hidayati, R. (2017). Keefektifan Setting TPS dalam Pendekatan Discovery Learning dan Problem Based Learning pada Pembelajaran Materi Lingkaran SMP. Jurnal Riset Pendidikan Matematika, 4(1), 78-86.

Ilmiyah, S. \& Marsiyah. (2013). Profil

Pemecahan Masalah Matematika Siswa SMP pada Materi Pecahan
Ditinjau dari Gaya Belajar. [Online]. Tersedia pada: http://dokumen.tips./documents/pr ofil-pemecahan-masalahmatematika-siswa-smp-pada-materipecahan-ditinjau.html

Lestari, K. E., \& Yudhanegara, M. R. (2015). Penelitian Pendidikan Matematika. Bandung: PT. Redika Aditama.

NCTM. (1989). Curriculumand Evaluation Standars for School Mathematics. Reston, VA: NCTM.

NCTM. (2000). Curriculum andEvaluation Standars for School Mathematics. United States of America: The National Council of Teacher of Mathematics, Inc.

Peraturan Menteri Pendidikan dan Kebudayaan Nomor 58 Tahun 2014 tentang Kurikulum 2013 Sekolah Menengah Pertama/Madrasah Tsanawiyah.

Pitriani, R., \& Afriansyah, E. A. (2017). Persepsi dalam Pembelajaran Pendekatan Keterampilan Proses terhadap Kemampuan Koneksi Matematis Siswa. Jurnal Gantang, 1(2), 15-24.

Pratiwi, E. A., Rusdi, A., \& Putri, A. D. (2017). Pengaruh Penggunaan Model Pembelajaran Mastery Learning (Belajar Tuntas) terhadap Kemampuan Pemecahan Masalah Matematika Siswa Kelas X SMA 'Aisyiyah 1 Palembang. Mosharafa: Jurnal Pendidikan Matematika, 6(1), 81-92. 
DOI: https://doi.org/10.31980/mosh arafa.v6i1.296

Putra, D. H, dkk. (2018). Kemampuan Pemecahan Masalah Matematis Siswa SMP pada Materi Bangun Ruang. JIPM: Jurnal Ilmiah Pendidikan Matematika, 6(2), 82-90.

Rahmatina, D. (2017). Penggunaan Perangkat Pembelajaran Geometri Ruang Berbasis ICT untuk Meningkatkan Kemampuan Berpikir Tingkat Tinggi Mahasiswa. Mosharafa: Jurnal Pendidikan Matematika, 6(1), 57-68. DOI: https://doi.org/10.31980/mosh arafa.v6i1.294

Shoimin, A. (2014). 68 Model Pembelajaran Inovatif dalam Kurikulum 2013. Yogyakarta: Ar-Ruzz Media.

Sopian, Y., \& Afriansyah, E. A. (2017). Kemampuan Proses Pemecahan Masalah Matematis Siswa Melalui Model Pembelajaran Creative Problem Solving dan Resource Based Learning. Jurnal Elemen, 3(1), 97107.

Supriatna, R., \& Afriansyah, E. A. (2018). Kemampuan Pemahaman Matematis Peserta Didik melalui Cooperative Learning Tipe Pair Checks VS Problem Based Learning. JPMI (Jurnal Pendidikan Matematika Indonesia), 3(1), 1-6.

Ulya, H. (2016). Profil Kemampuan Pemecahan Masalah Siswa Bermotivasi Belajar Tinggi
Berdasarkan Ideal Problem Solving. Jurnal Konseling GUSJIGANG, 2(1), 90-96.

Utami, R. W. \& Wutsqa, D. U. (2017). Analisis Kemampuan Pemecahan Masalah Matematika dan Self-Efficacy Siswa SMP Negeri di Kabupaten Ciamis. Journal UNY: Jurnal Riset Pendidikan Matematika, 4(2), 166175.

Wardani, S. (2012). Pembelajaran Inkuiri Model Silver untuk Mengembangkan Kemampuan Pemecahan Masalah dan Disposisi Matematik Siswa Sekolah Menengah Atas. Mosharafa: Jurnal Pendidikan Matematika, 1(1), 9-16. DOI: https://doi.org/10.31980/moshar afa.v1i1.167

\section{Riwayat Hidup PENULIS}

Hilmi Ramdayani Fauziah Nur Hanifah, S.Pd.

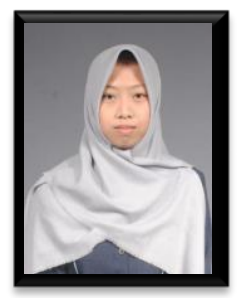

Lahir di Garut, 18 Januari 1998. Studi S1 Pendidikan Matematika IPI Garut, lulus tahun 2019.

\section{Reni Nuraeni, M.Pd.}

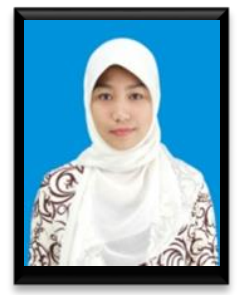

Lahir di Garut, 15 Agustus 1988. Studi S1 Pendidikan Matematika STKIP Garut, lulus tahun 2010; S2 Pendidikan Matematika UPI Bandung, lulus tahun 2014. 